\title{
RADIOCARBON CONCENTRATION AND ORIGIN OF THERMAL KARST WATERS IN THE REGION OF THE BÜKK MOUNTAINS, NORTHEASTERN HUNGARY
}

\author{
EDE HERTELENDI, ${ }^{1}$ MIHÁLY VERES, ${ }^{1}$ ISTVÁN FUTO, ${ }^{1}$ ÉVA SVINGOR, ${ }^{1}$ LAJOS MIKÓ, ${ }^{2}$ \\ LÁSZLÓ LÉNÁRT, ${ }^{3} J O Z S E F$ DEÁK ${ }^{4}$ and MIKLOSS SÜVEGES
}

\begin{abstract}
Karst springs are abundant in Hungary, and many are thermal (temperatures $>30^{\circ} \mathrm{C}$ ). As thermal springs are a significant part of Hungary's water resources, it is important to quantify their travel times in the karst systems. Thus, we chose to measure $\mathrm{T}$ and $\delta^{18} \mathrm{O}$ in the water and $\delta^{13} \mathrm{C}$ and ${ }^{14} \mathrm{C}$ in dissolved inorganic carbon (DIC) in water from 50 thermal and nonthermal springs and wells in the Bükk Mountains, northeastern Hungary. Environmental isotope data confirm the karst waterflow pattern implied by earlier studies. We found the water in warm springs and boreholes to be mixtures of cold young and old thermal water. We also determined short mean-residence times for some large cold springs. The ${ }^{14} \mathrm{C}$ activities measured in these springs indicate that the recharge area of the karst aquifer is open to the atmosphere, and atmospheric $\mathrm{CO}_{2}$ contributes to the ${ }^{14} \mathrm{C}$ activity of these groundwaters. We observed good correlation between ${ }^{14} \mathrm{C}$ and ${ }^{3} \mathrm{H}$ activities and we determined negative correlations between ${ }^{14} \mathrm{C}$ concentration and $\delta^{13} \mathrm{C}$ values and temperature. From the $\delta^{18} \mathrm{O}$ values of the oldest thermal waters, we attribute their origin to precipitation during colder temperatures than at present.
\end{abstract}

\section{INTRODUCTION}

Precipitation in the southwestern Bükk Mountains, northeast Hungary, percolates into the karstified layers down to bedrock (Figs. 1, 2). In the limestone, the water continues dripping toward the Great Hungarian Plain to successively greater depths, gradually assuming the higher temperatures prevailing there. This heated karst water emerges along fault lines to the surface and forms warm springs (Schréter 1923). The karst water of $30^{\circ} \mathrm{C}$ temperature and $30 \mathrm{~m}^{3} \mathrm{~min}^{-1}$ yield emerging to the surface in the warm springs around Eger corresponds to a thermal output of $4 \times 10^{7} \mathrm{~W}$. An area $>400 \mathrm{~km}^{2}$ would be needed to absorb this vast heat, even if the entire terrestrial heat flux were used to heat this amount of water. In view of the fact that the warm springs are 5-10 km from the surface outcrops of the karst in the southwestern Bükk Mountains, direct percolation and heating cannot be the only source of the warm water. This assumption apparently conflicts with the isochronous map based on ${ }^{14} \mathrm{C}$ data. The ${ }^{14} \mathrm{C}$ concentration in DIC (dissolved inorganic carbon) and ${ }^{3} \mathrm{H}$ concentration decrease sequentially from the surface karst toward the warm springs and the more distant thermal waters. Water-temperature increase follows the same pattern. Water in the warm springs and wells of the area is mixed and the ${ }^{14} \mathrm{C}$ and ${ }^{3} \mathrm{H}$ concentrations indicate the mix proportion.

\section{THE HYDROGEOLOGY OF THE AREA}

The oldest rocks in the Bükk Mountains are Upper Carboniferous shales and sandstone underlying gray limestone. The Carboniferous sequences are ca. $1100 \mathrm{~m}$ thick; they are covered in the Lower Permian by schist and dolomite (170-250 m), and in the Upper Permian, dolomites and limestone (200-250 m) were deposited. Marine sedimentation was continuous in the Permian/Triassic boundary. The main mass of the mountains consists of $c a .3 .5 \mathrm{~km}$ Triassic sequences. The oldest is oolitic limestone, followed by sandy, foliated limestone. The Middle Triassic consists of limestone and dolomite with interlayered shales, slates, sandstone and altered volcanic submarine rocks (diabase, rhyolite).

\footnotetext{
${ }^{1}$ Institute of Nuclear Research of the Hungarian Academy of Sciences, P.O. Box 51, H-4001 Debrecen, Hungary ${ }^{2}$ Hungarian Geological Survey, Regional Geological Service Debrecen, Csap6 Street 78-80, H-4029 Debrecen, Hungary ${ }^{3}$ Department of Hydrogeology and Engineering Geology, University of Miskolc, Egyetemváros, H-3515 Miskolc, Hungary ${ }^{4}$ Research Institute for Water Resources, P.O. Box 27, H-1453 Budapest, Hungary
} 


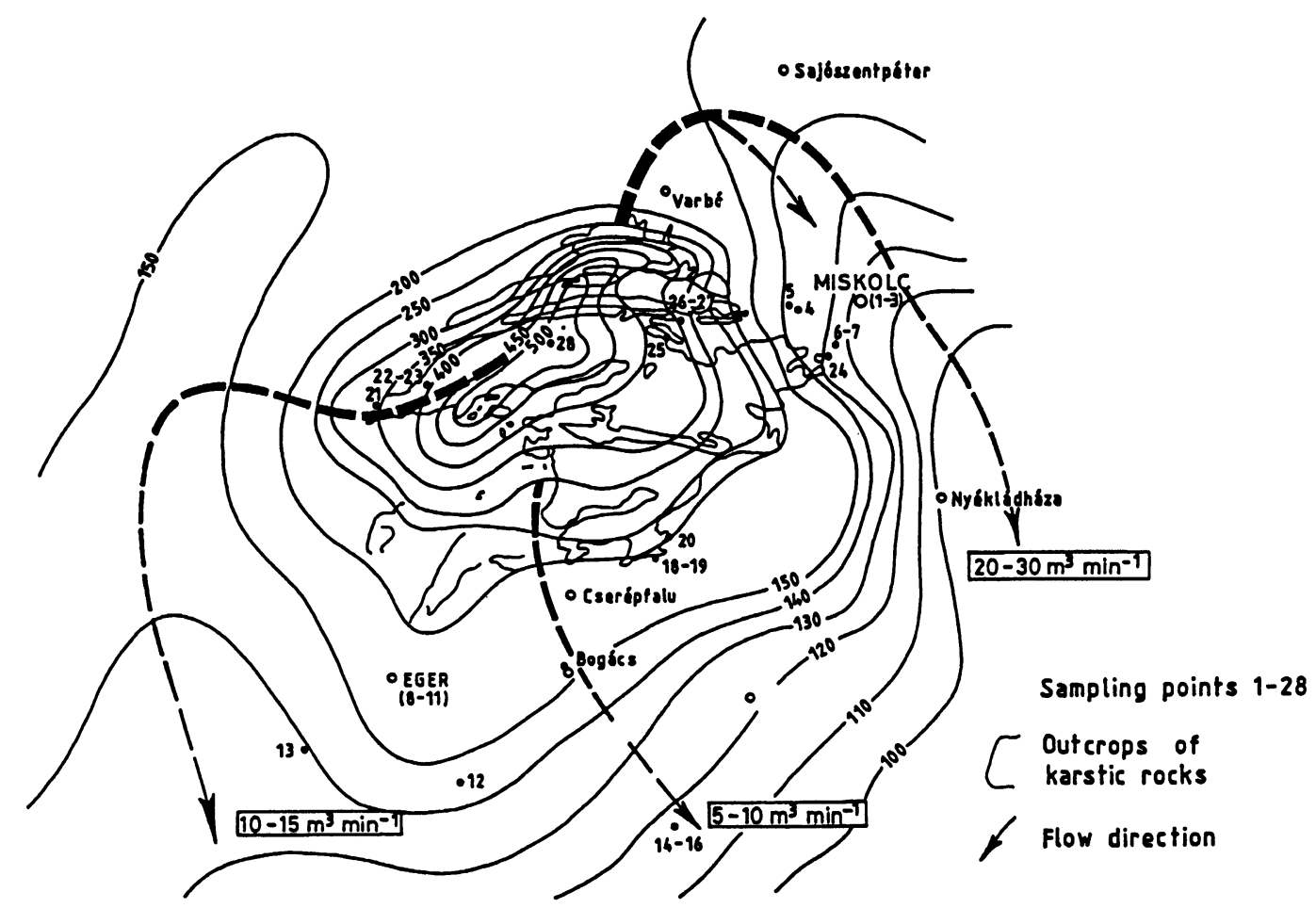

Fig. 1. Piezometric contour of the Bükk Mountains with sampling points

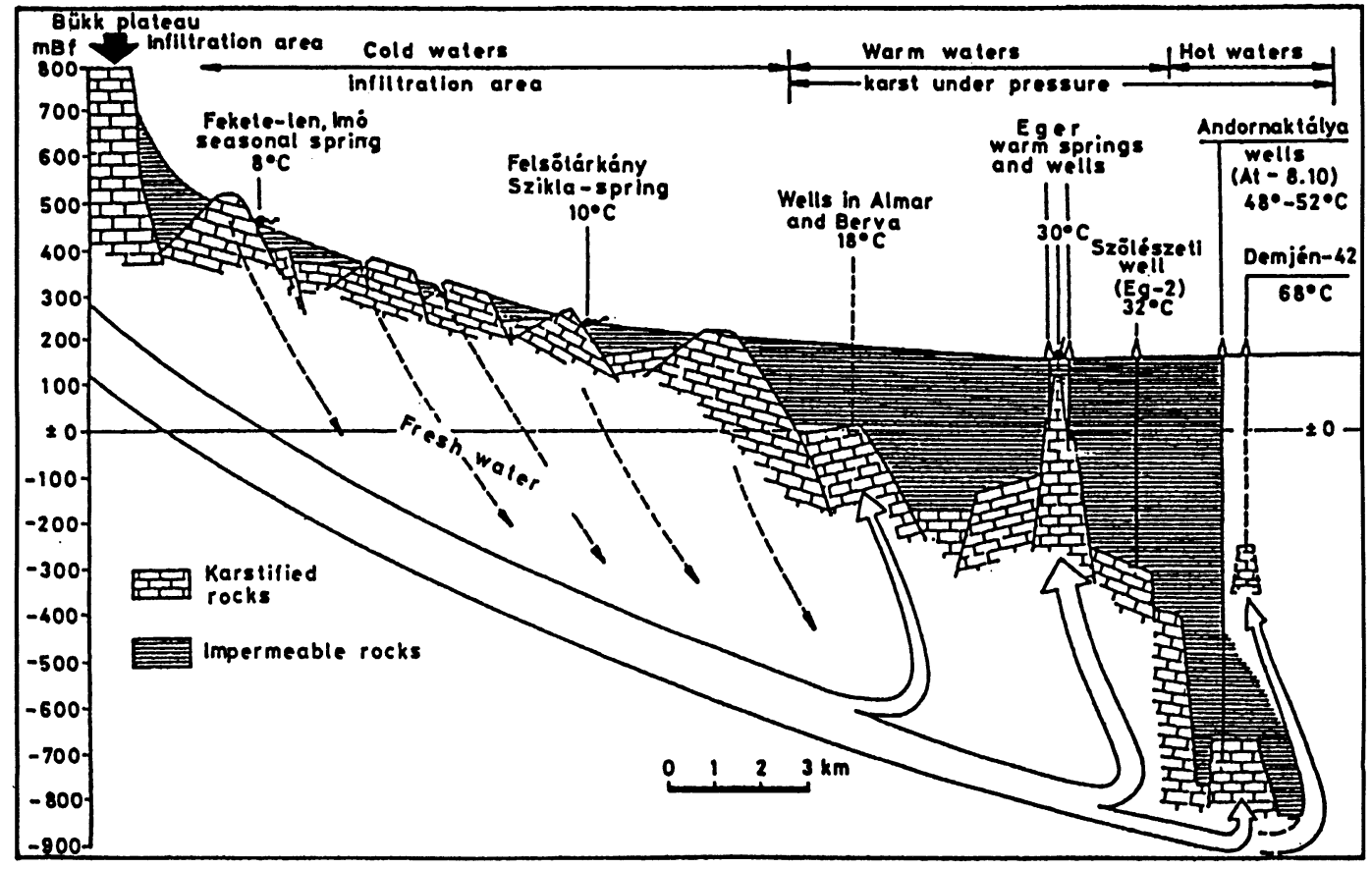

Fig. 2. Geological profile of the thermal karst system near Eger 
The most characteristic feature of the Bükk Mountains is the central plateau, which is $22 \mathrm{~km}$ long and $3-5 \mathrm{~km}$ wide; its average height is $c a .900 \mathrm{~m}$. The limestone and dolomite of the plateau are strongly karstified. Karstification started when the rocks were on the surface and continued after they were covered. At present the karstic area is partly exposed; in other places its uncovering is in progress.

We know of nearly 1000 caves in the Bükk Mountains. In some areas, dripstones and other calcareous carbonates-material suitable for isotope-hydrogeological studies-can be found. The number of karst springs is similar to that of the caves. $\mathrm{Ca} .12$ production wells and monitoring boreholes facilitate the observation of the karst water level.

The structure of the mountains is characterized by an older folded and overthrusted system and a younger, perpendicular tension system of northwestern-southeastern strike. The movements of the groundwater occur along these zones, which are confined by three more or less parallel (easternwestern strike) zones of impermeable, mostly volcanogenic rocks. The topography of springs, caves and dolines reflects the structure of the mountains. A great reverse fault (Darnó tectonic zone), striking north-northeast-south-southwest borders the Bükk Mountains. Hydrocarbon and $\mathrm{CO}_{2}$ reservoirs and aquifers filled partly with water can be found along this zone.

\section{RESUlts AND DISCUSSION}

\section{Radiocarbon}

The ${ }^{14} \mathrm{C}$ concentration of DIC (Table 1) positively correlates with the ${ }^{3} \mathrm{H}$ concentration of water (Fig. 3). The highest measured values were in Szalajka, Szikla and Szinva springs, the lowest ${ }^{14} \mathrm{C}$ concentrations were from deep wells with hot karstic waters. The wide range covered by ${ }^{14} \mathrm{C}$ values reflects the highly variable hydrogeological and hydrochemical conditions in the area under investigation. Low ${ }^{14} \mathrm{C}$ values suggest high mean-residence times of groundwater, which correlate positively with high water temperatures. The $\delta^{13} \mathrm{C}$ values increase with decreasing ${ }^{14} \mathrm{C}$ concentration in the thermal part of the karst system (Figs. 3, 4). Dissolution of $\mathrm{CaCO}_{3}$ and excess $\mathrm{CO}_{2}$ lower pMC values (Table 1, Fig. 4).

\section{Tritium}

We measured the highest ${ }^{3} \mathrm{H}$ concentrations in the following springs: Szalajka; Szikla; Szinva (main); Anna I; Anna III; Jávorkút; and Mónosbél. Very low ${ }^{3} \mathrm{H}$ concentrations (below the detection limit of $1 \mathrm{TU}$ ) were obtained for deep wells. We measured intermediate values for warm springs in the Eger and Miskolc region, which indicated a mixture of recently recharged and older hot water (Table 1).

$\delta^{13} \mathrm{C}$

The $\delta^{13} \mathrm{C}$ values are between $-12 \%$, typical of the fresh karst water, and $0 \%$, in the Zsóri I-VI wells, whereas we found intermediate values in the warm springs. The large scatter of $\delta^{13} \mathrm{C}$ values reflects different degrees of chemical interaction of water with aquifer rock. Due to the large amount of dissolved carbonates and excess $\mathrm{CO}_{2}, \delta^{13} \mathrm{C}$ values approach $0 \%$ in old karst water.

$\delta^{18} \mathrm{O}$

The $\delta^{18} \mathrm{O}$ values of cold springs waters are nearly uniform (Table 1, Fig. 3), between -10 and $-11 \%$, corresponding to the weighted mean of $\delta^{18} \mathrm{O}$ values of the precipitation at the height of the central outcrops. Surprisingly, the $\delta^{18} \mathrm{O}$ values of warm springs, characterized in earlier studies as a mixture of old warm and young cold water, are not significantly different from those of the cold springs. 


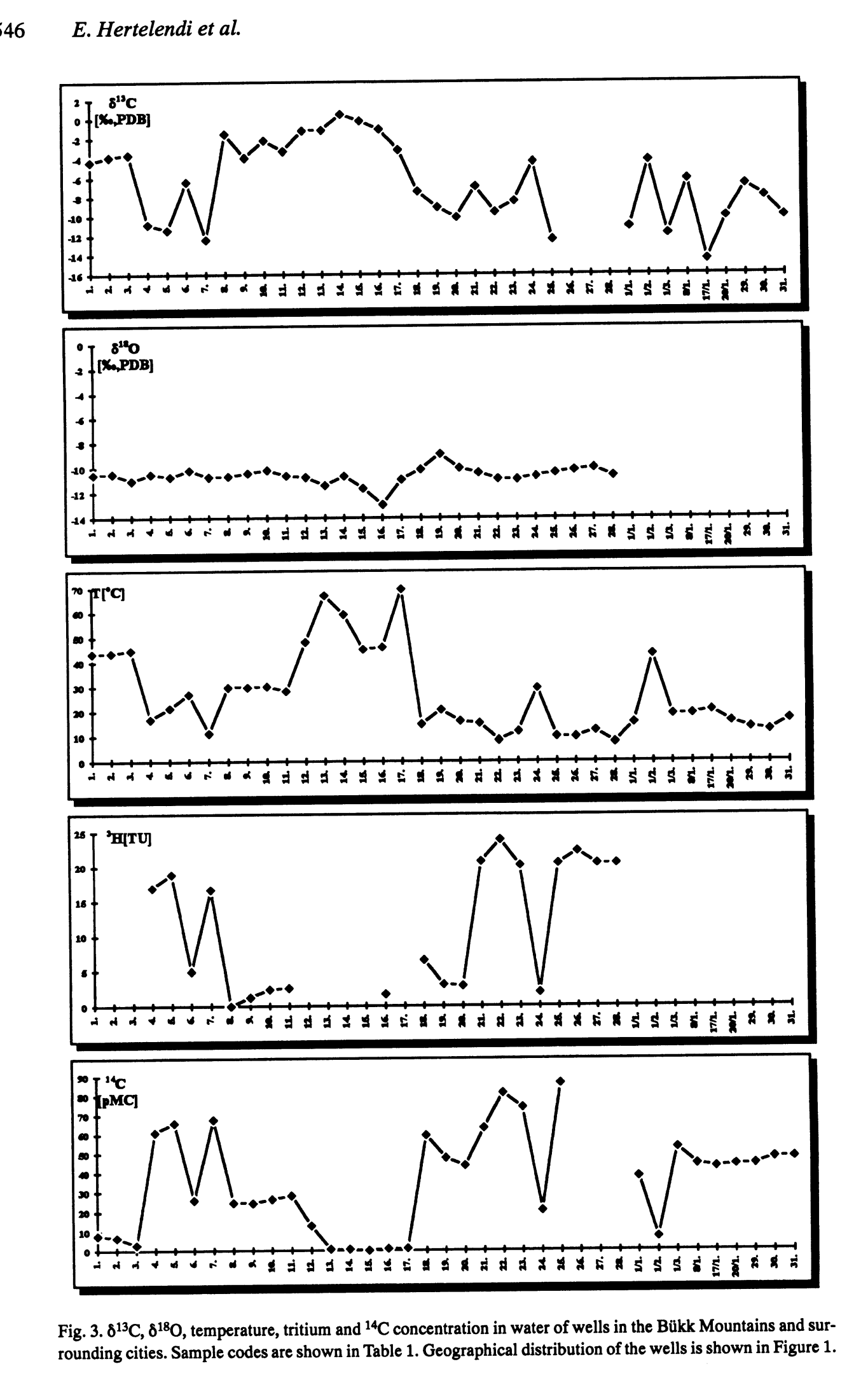


TABLE 1. Stable isotope compositions, radiocarbon and tritium concentrations and temperatures of springs and wells in the Bükk Mountains and surrounding cities. Figure 1 shows sampling points.

\begin{tabular}{|c|c|c|c|c|c|}
\hline Sample code & $\begin{array}{c}\delta^{13} \mathrm{C} \\
{[\% \circ]} \\
\text { (PDB) }\end{array}$ & $\begin{array}{c}\delta^{18} \mathrm{O} \\
{[\% \circ]} \\
\text { (PDB) }\end{array}$ & $\begin{array}{c}{ }^{14} \mathrm{C} \\
{[\mathrm{pMC}]}\end{array}$ & $\begin{array}{c}{ }^{3} \mathrm{H} \\
{[\mathrm{TU}]}\end{array}$ & $\begin{array}{c}\text { Temp. } \\
\left({ }^{\circ} \mathrm{C}\right)\end{array}$ \\
\hline 1. Aug.20.II.well (Miskolc) & -4.34 & -10.52 & 7.9 & & 43.6 \\
\hline 2. Kertészeti well (Miskolc) & -3.82 & -10.45 & 6.7 & & 43.7 \\
\hline 3. Erzsébet square (bath) & -3.59 & -11.00 & 2.9 & & 44.9 \\
\hline 4. Tó spring (Miskolc) & -10.79 & -10.50 & 61.2 & 17 & 17 \\
\hline 5. Szent György spring & -11.40 & -10.69 & 66 & 18.9 & 21.4 \\
\hline 6. Szerelem island (Miskolc) & -6.35 & -10.17 & 26.1 & 5 & 27.2 \\
\hline 7. Új well (Miskolc) & -12.35 & -10.72 & 67.9 & 16.7 & 11.3 \\
\hline 8. Török spring (Eger) & -1.47 & -10.66 & 24.8 & $<1$ & $28-32$ \\
\hline 9. Tükör spring (Eger) & -3.89 & -10.43 & 24.5 & 1.3 & $28-32$ \\
\hline 10. Szent-József well (Eger) & -2.16 & -10.16 & 26.4 & 2.4 & 30.3 \\
\hline 11. Petớfi-tér I. well (Eger) & -3.26 & -10.62 & 28.3 & 2.6 & 28.3 \\
\hline 12. Andornaktálya AT 8 & -1.14 & -10.76 & 12.8 & & 48.2 \\
\hline 13. Demjén 42 & -1.10 & -11.39 & 0.6 & & 67 \\
\hline 14. Zsóri I./A (Mezókövesd) & 0.51 & -10.65 & 0.5 & & 59.3 \\
\hline 15. Zóri II. (Mezókövesd) & -0.18 & -11.62 & 0 & & 45.2 \\
\hline 16. Zóri IV. (Mezókövesd) & -1.03 & -12.96 & 0.8 & 1.7 & 46 \\
\hline 17. Bogács I. well & -3.13 & -10.95 & 1.1 & & 69.6 \\
\hline 18. Kács main spring & -7.43 & -10.11 & 59.4 & 6.6 & 14.8 \\
\hline 19. Kács spring & -9.07 & -8.90 & 47.6 & 3.1 & 20.5 \\
\hline 20. Sály spring & -10.10 & -10.01 & 43.5 & 2.9 & 15.9 \\
\hline 21. Mónosbél spring & -6.90 & -10.43 & 63.2 & 20.8 & 15.1 \\
\hline 22. Szalajka spring & -9.58 & -10.91 & 81.4 & 23.9 & 8.4 \\
\hline 23. Szikla spring & -8.44 & -10.94 & 73.9 & 20.2 & 11.8 \\
\hline 24. Tapolca cave (Miskolc) & -4.38 & -10.67 & 20.5 & 1.9 & 29.5 \\
\hline 25. Szinva main spring (Miskolc) & -12.44 & -10.41 & 86.3 & 20.5 & 9.9 \\
\hline 26. Anna I (Miskolc) & & -10.21 & & 22.3 & $9.6-9.7$ \\
\hline 27. Anna III (Miskolc) & & -10.02 & & 20.5 & 12.2 \\
\hline 28. Jávorkút & & -10.65 & & 20.5 & 7.6 \\
\hline 1/1. Miskolc AFIT & -11.12 & & 38.1 & & 15.3 \\
\hline 1/2. Miskolc Húsipar & -4.24 & & 6.9 & & 43.1 \\
\hline 1/3. Miskolc Drótgyár & -11.84 & & 52.9 & & 18.6 \\
\hline 8/1. Berva Újkút & -6.21 & & 44.2 & & 18.8 \\
\hline 17/1. Bogács Községikút & -14.55 & & 42.7 & & 20.2 \\
\hline 20/1. Sály & -10.08 & & 43.7 & & 15.7 \\
\hline 29. Noszvaj Forrókút & -6.74 & & 44.1 & & 13.2 \\
\hline 30. Barátrét 1 & -7.94 & & 47.6 & & 12.2 \\
\hline 31. Almár 0 & -10.05 & & 47.8 & & 16.6 \\
\hline
\end{tabular}

Only the Eger Demjén, Miskolc Erzsébet square (bath) and Mezókövesd 4.K hot-water wells show lower $\delta^{18} O$ values than $-11 \%$, which imply that they originate from precipitation during colder temperatures than at present (Table 1). 


\section{The Origin of Water in Springs}

The ${ }^{3} \mathrm{H}$ concentrations equal to $23.9 \mathrm{TU}$ in Szalajka spring, the $20.2 \mathrm{TU}$ in Szikla spring at Felsốtárkány, and 20.5 TU in Szinva spring in Miskolc indicate very recent, rapidly flowing water (Table 1). The ${ }^{14} \mathrm{C}$ concentrations in DIC of 81.4, 73.9 and 86.3 pMC do not reflect their sample
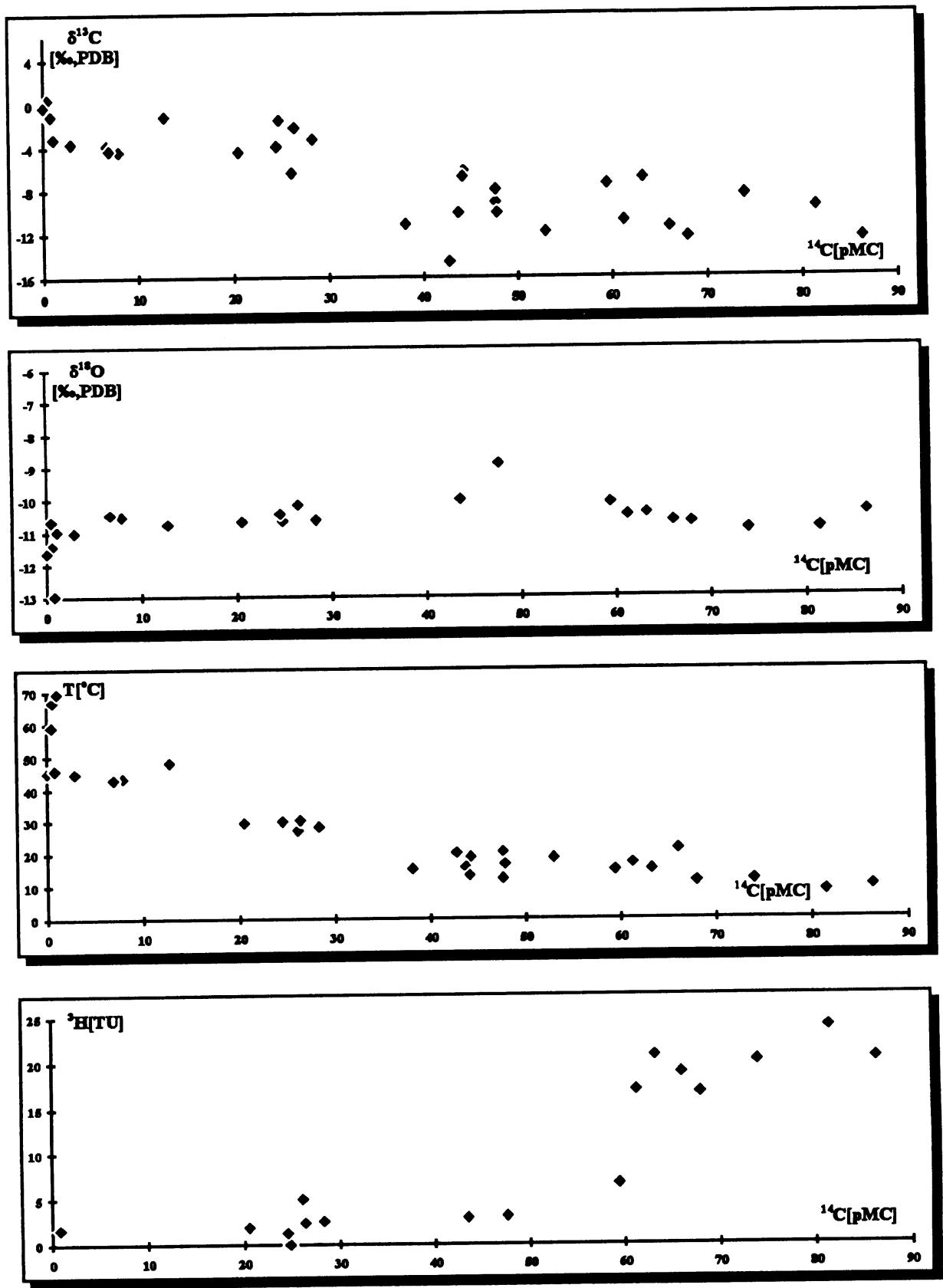

Fig. $4 . \delta^{13} \mathrm{C}, \delta^{18} \mathrm{O}$, temperature and tritium concentration as a function of ${ }^{14} \mathrm{C}$ concentration. Sample codes are shown in Table 1. The geographical distribution of the wells is shown in Figure 1. 
ages, which are very short compared to the half-life of ${ }^{14} \mathrm{C}$. The ${ }^{14} \mathrm{C}$ activity of groundwater depends on the processes in the topsoil and along the recharge zones that contribute to the ${ }^{14} \mathrm{C}$ activity and $\delta^{13} \mathrm{C}$ content of the dissolved bicarbonates. Several theoretical models for groundwater ${ }^{14} \mathrm{C}$ activity exist (Tamers 1967; Tamers and Scharpenseel 1970; Pearson and Hanshaw 1970; Mook 1976; Fontes and Garnier 1979; Eichinger 1983). The calculation of Krajcar-Bronic et al. (1986) showed that these models give substantially lower initial ${ }^{14} \mathrm{C}$ activities than the experimental data. The high ${ }^{14} \mathrm{C}$ concentrations measured for springs in the Bükk Mountains indicate that the recharge area of the karst system is open to the atmosphere. The tritium content of $17 \mathrm{TU}$ in To spring, 18.9 TU in Szent György spring and $16.7 \mathrm{TU}$ in Új well are appreciably lower. These springs and the Új well are situated in the vicinity of the recharge area (Fig. 1.). Fresh karst water flowing in the wide passages at relatively high velocities arrives in $<30 \mathrm{yr}$ at the Új well and the Tó and Szent György springs, whereas appreciably older karst water enters the wells and springs from narrow fissures. Thus, bodies of water of different ages mix, causing lower tritium concentrations, and explaining the intermediate values of ${ }^{14} \mathrm{C}$ concentration.

The tritium concentration of 1.3 TU in Tükör spring and 2.4 TU in Szent József well do not confirm the earlier assumption, according to which the masses of water in Tükör spring contain unconfined groundwater as well. This groundwater may mix with the karst water of Tükör spring when the latter emerges from the limestone rock to the surface and passes through the gravel alluvium of Eger Creek.

The lowest ${ }^{14} \mathrm{C}$ activities $(<1.1 \%)$ were measured in wells near the villages of Mezókövesd, Bogács and Demjén. These waters do not contain measurable $(>1 \mathrm{TU})$ tritium; the $\delta^{18} \mathrm{O}$ and $\delta^{13} \mathrm{C}$ values are between $(-10.65,-12.69) \% o$ and $(+0.5,-3.13) \%$, respectively. The age of these waters cannot be determined by ${ }^{14} \mathrm{C}$ dating because $\delta^{13} \mathrm{C}$ values clearly indicate dissolution of the limestone and the effect of excess $\mathrm{CO}_{2}$.

Figure 4 shows that the tritium and ${ }^{14} \mathrm{C}$ concentrations of the water in wells and springs are strongly correlated. Negative correlations are observed between ${ }^{14} \mathrm{C}$ concentration of DIC and temperature and stable carbon isotope ratios.

\section{Conclusion}

This isotope hydrological investigation led to several new insights and supported earlier concepts:

1. The results of the environmental isotope analyses on karst waters at Eger and in the surrounding area confirm the karst water pattern implied by earlier studies. The water emerging in the warm springs and boreholes at Eger is a mixture of fresh cold water and older thermal karst water. We did not observe recent groundwater from unconfined origins in the Tükör spring.

2. Our measurements indicate that the recharge area of the karst aquifer in the Bükk Mountains is open to the atmosphere and atmospheric $\mathrm{CO}_{2}$ contributes to the ${ }^{13} \mathrm{C}$ content and the ${ }^{14} \mathrm{C}$ activity
of groundwater.

3. We found positive correlation between ${ }^{14} \mathrm{C}$ and tritium activities, and negative correlations between ${ }^{14} \mathrm{C}$ concentration and $\delta^{13} \mathrm{C}$ values and temperature.

4. The $\delta^{18} \mathrm{O}$ values of the oldest water imply that it originates from precipitation during colder temperatures than at present.

\section{ACKNOWLEDGMENT}

The authors thank M. Mogyorósi for her technical help. 


\section{REFERENCES}

Eichinger, L. 1983 A contribution to the interpretation of ${ }^{14} \mathrm{C}$ groundwater ages considering the example of a partially confined sandstone aquifer. In Stuiver, M. and Kra, R. S., eds., Proceedings of the 11th International ${ }^{14} \mathrm{C}$ Conference. Radiocarbon 25(2): 347-356.

Fontes, J.-Ch. and Garnier, J. M. 1979 Determination of the initial ${ }^{14} \mathrm{C}$ activity of the Total Dissolved Carbon: A review of the existing models and new approach. Water Resources Research 14(2): 399-413.

Krajcar-Bronić, I., Horvatincić, N., Srdoc, D. and Obelić, B. 1986 On the initial ${ }^{14} \mathrm{C}$ activity of karst aquifers with short mean residence time. In Stuiver, M. and Kra, R. S., eds., Proceedings of the 12th International ${ }^{14} \mathrm{C}$ Conference. Radiocarbon 28(2A): 436-440.

Mook, W. G. 1976 The dissolution-exchange model for dating ground water with ${ }^{14} \mathrm{C}$, interpretation of environmental isotope and hydrochemical data. Groundwater Hydrology. Vienna, IAEA: 213-225.

Pearson, F. J. and Hanshaw, B. B. 1970 Sources of dissolved carbonate species in ground water and their effects on ${ }^{14} \mathrm{C}$ dating. Isotope Hydrology. Vienna, IAEA: 271-285.

Schreter, Z. 1923 The warm springs at Eger. A Magyar Királyi Földtani Intézet Evvoönyve 25(4): 25-41.

Tamers, M. A. 1967 Surface-water infiltration and ground water movement in arid zones of Venezuela. Isotope Hydrology. Vienna, IAEA: 339-353.

Tamers, M. A. and Scharpenseel, H. W. 1970 Sequential sampling of radiocarbon in ground water. Isotope $\mathrm{Hy}$ drology Vienna, IAEA: 241-257. 